\title{
Does IFRS Implementation Improve Qualitative Characteristics of Accounting Information: Evidence from Saudi Commercial Banks
}

\author{
Ibrahim El-Sayed Ebaid ${ }^{1}$ \\ ${ }^{1}$ Associate Professor, Accounting Department, Tanta University, Egypt, and Umm Al-Qura University, \\ Saudi Arabia
}

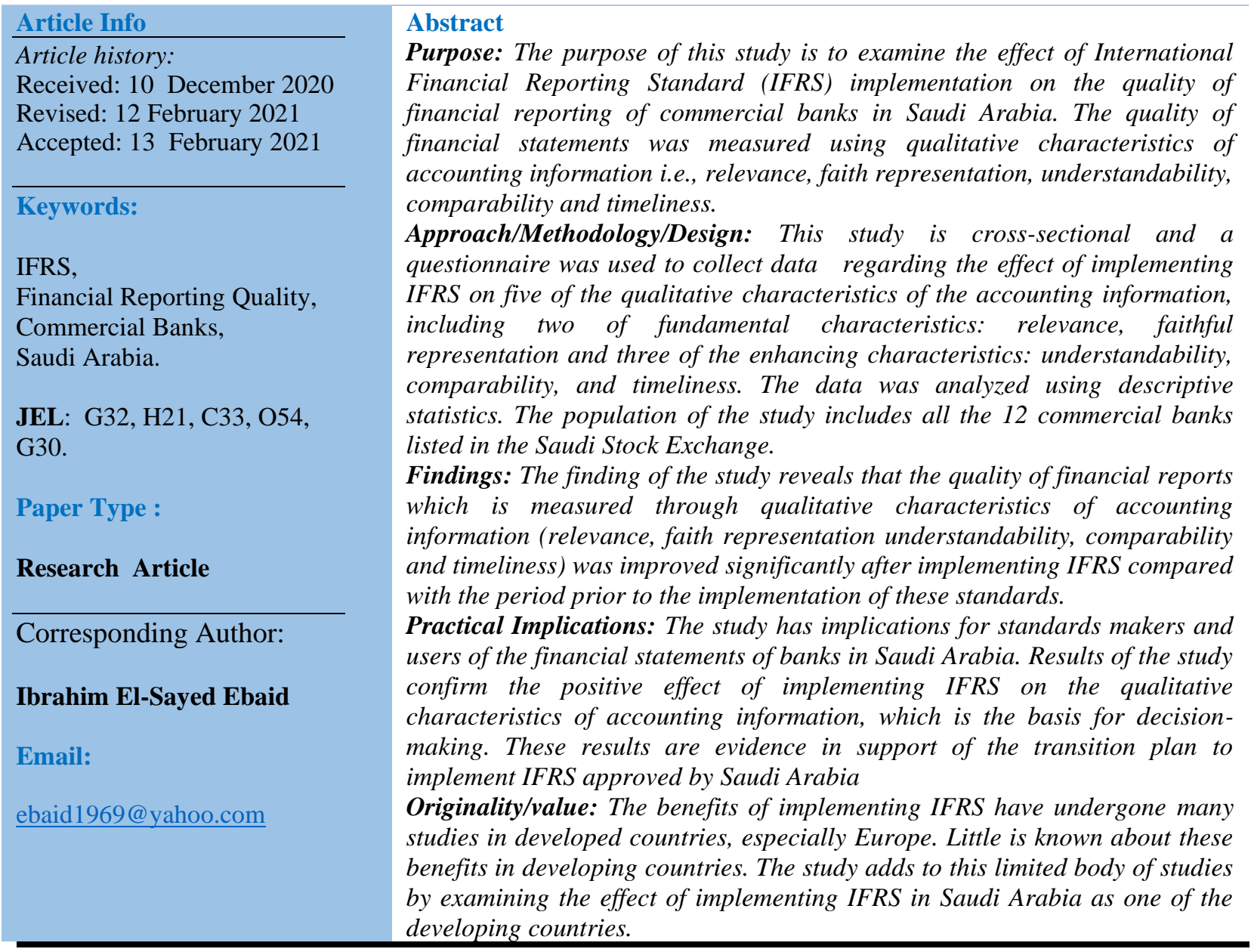

\section{Introduction}

International Financial Reporting Standards IFRS can be defined as an integrated set of standards that guide companies when measuring, recognizing and reporting the financial transactions that they undertake. Efforts to harmonize accounting standards in order to reach an integrated set of standards that can be applied on an international scale began in 1973 with the establishment of the International Accounting Standards Committee (IASC), which came into existence on June 29, 1973. In 1997 the committee began developing standards by forming a special committee to deal with the issue of financial instruments and financial derivatives. In 1998, four European countries, namely England, Germany, France and Belgium, issued national 
laws that allow large companies to apply international financial reporting standards within each country. As a result of this, the finance ministers of the Group of Seven industrialized countries issued a statement calling for the adoption and support of international accounting standards. In 2000, the Basel Committee, which is concerned with banking affairs, declared its support and acceptance of international accounting standards (IASs), and in the same year, 30 standards were accepted by the International Organization of Exchanges (IOSCO), whereby companies were allowed to use these standards outside the borders of their original home. In 2002, the European Union (EU) Parliament approved a regulation (Regulation (EC) 1606/2002) that mandates all companies registered in the EU stock markets to adopt International Financial Reporting Standards (IFRS) in preparing consolidated and stand-alone financial statements commencing after 1 January 2005. Since then, IFRS has begun to spread in all countries of the world. For example, the International Accounting Standards Board stated on its website that the number of countries adopting International Financial Reporting Standards by the end of 2017 had exceeded 150 countries. The globalization of financial markets at the present time has increased the need for a unified set of accounting standards for measurement and reporting that are applicable on an international scale, as accounting information is one of the main sources for dealing and making decisions in these markets (Surianti \& Yadiati, 2017).

The primary goal of accounting standard setters (i.e., FASB and IASB) is to issue accounting standards that lead to improving the quality of financial statements. The adoption of IFRS has received considerable research interest and there have been a growing number of studies conducted to explore the impact of mandatory/voluntary IFRS adoption on financial statements quality. However, one of the major challenges in accounting literature is how to measure this quality in a practical way? Different groups of users may have different preferences; as a result, these groups may have a different perception of the quality of the different types of information included in financial reports. In addition, users belonging to the same group (investors, for example) may have a different perception of the quality of the same type of information. As a result, measuring the quality of financial reports and the information they contain directly is very difficult (Botosan, 2004). Prior studies have tried to measure the quality of the financial reports and the information they contain indirectly by testing some factors that are believed to affect the quality of financial reports such as earnings management, restatements, timely loss recognition and value relevance (e.g., Schipper \& Vincent, 2003; Cohen et al. 2004., Barth et al., 2008., Liu et al., 2011; Chua et al., 2012; Dimitropoulos et al., 2013; Junior et al., 2017; Trimble, 2018; Morais et al., 2018; Key \& Kim, 2020).

The Conceptual Framework for Financial Reporting issued by the International Accounting Standards Board has stated that "the objective of financial statements is to provide information on the financial position, performance and change in the financial position of a company that is useful to a wide range of users in making economic decisions" IASB $(2008,2013)$. Providing high-quality information in the published financial reports is one of the important matters, as it positively affects the decisions of the providers of capital and other stakeholders in the company, and then it increases the quality of decisions to allocate available resources and thus increasing the efficiency of the capital market in general. Accordingly, some prior research shows that the main test of the quality of financial statements is through examining the quality of disclosed 
information in a company's financial reports, specifically, examining the qualitative characteristics of this information (Agyei-Mensah, 2013). These qualitative characteristics enhance the facilitation of assessing the usefulness of financial reports, which will also lead to a high level of quality. As it is defined in the Conceptual Framework for Financial Reporting of IASB, the qualitative characteristics of financial reporting information were divided into fundamental qualitative characteristics and enhancing qualitative characteristics. Fundamental qualitative characteristics include relevance, faithful representation, while enhancing qualitative characteristics include understandability, comparability, verifiability, and timeliness.

The objective of this study is to examine whether the implementing of IFRS in Saudi commercial banks improves the financial statements quality. A questionnaire survey was used to explore the opinions of financial statements preparers in Saudi commercial banks regarding the effect of implementing IFRS on five of the qualitative characteristics of the accounting information, including two of fundamental characteristics: relevance, faithful representation and three of the enhancing characteristics: understandability, comparability, and timeliness. More specifically, the main question in this study is: does the implementation of IFRS lead to an improvement in the qualitative characteristics of accounting information for Saudi commercial banks after the implementation than they were before the implementation of these standards? To answer the question raised, section 2 of this study provides an institutional background on the adoption of IFRS in Saudi Arabia. Section 3 examines extant literature on the impact of IFRS on qualitative characteristics of accounting information. Section 4 explains the research method used in this study and Section 5 reports the result of the study, while Section 6 is conclusions.

\section{Institutional Context of Saudi Arabia}

Since Saudi Arabia joined the Group of Twenty Finance Ministers and Central Bank Governors (G20) in 2009, the adoption of IFRS has been viewed as an important milestone in the country's future economic development and has been working towards this end ever since. In April 2016, Saudi Arabia announced an ambitious economic program called "Saudi Arabia's Vision for 2030" which expresses Saudi Arabia's long-term goals and expectations and it is built upon the country's unique strengths and capabilities. This vision guides the country's aspirations towards a new phase of economic development aims to diversify sources of income instead of relying solely on oil, creating more job opportunities via encouraging investment, both domestic and foreign, encouraging the major Saudi corporations to expand across borders and take their rightful place in global markets and providing better opportunities for partnerships with the private sector. In an era of globalization of businesses and markets, financial information prepared and audited according to national accounting and auditing standards no longer satisfies the needs of users whose decisions are more international in scope. Saudi Arabia has recognized the need to participate in the opportunities offered by globalization. Consequently, to attract direct foreign investment to the country, The Saudi Organization of Certified Public Accountants (SOCPA), in a parallel step with the preparation of Saudi Arabia's Vision for 2030, has approved an IFRS convergence plan, called the "SOCPA Project for Transition to International Accounting \& Auditing Standards" in 2012. In 2016, SOCPA adopted all of the IFRS Standards (including Interpretations) based on the IFRS 2017 Red Book, without amending any requirements in those standards. Under this convergence plan, all listed companies are required 
to adopt IFRS for financial periods beginning on or after January 1, 2017 with some modifications resulting in additional disclosures and ensuring compliance with Shariah as a single set of high quality, understandable, enforceable and globally accepted standards for financial reporting. Also, the Saudi Arabian Monetary Authority (SAMA) requires all banks and insurance companies to use IFRS Standards. SOCPA argues that the transition to IFRS promises transparent, comparable and consistent financial information to guide investors in making optimal investment decisions. Some of the key benefits that the companies will enjoy from IFRS adoption include increased foreign direct investment (FDI), enhanced quality reporting, transparency and comparability, and more transparency to perform risk assessments on financial statements and other ratios. In a parallel step, SOCPA has endorsed an integrated set of auditing standards based basically on international auditing standards. All accounting firms in Saudi Arabia are required to adopt these integrated set of auditing standards for financial periods beginning on or after January 1, 2017. Because the business sector is important in achieving the objectives of Saudi Arabia's economic vision 2030, and this includes not only large (listed) entities but the much more numerous small and medium-sized entities (SMEs), SOCPA adopted IFRS for SMEs as of January 2018. All SMEs in Saudi Arabia are required to adopt IFRS for SMEs for financial periods beginning on or after January 1, 2018. SOCPA has adopted the 2015 version of the IFRS for small and medium-sized entities (SMEs) Standard.

\section{Literature Review}

As mentioned previously, most of the prior studies that have examined the effect of implementing IFRS on the quality of financial reports have examined this effect indirectly from the perspective of earnings management practices, restatements, timely loss recognition and value relevance. This could explain the limitations of the prior studies that have examined the effect of implementing IFRS on the qualitative characteristics of accounting information. Yacoob and Ahmad (2011) studied a sample of listed companies in Malaysia to determine the extent of improvement in the timeliness of accounting information after the adoption of IFRS. They concluded that the timeliness of accounting information has decreased in the period after the adoption of IFRS compared to the period preceding the adoption of these standards. Abdurazak (2011) studied the effect of implementing IFRSs on the quality of financial reporting for small and medium enterprises in Kenya. The quality of financial reports was measured a set of accounting information characteristics, which are faithful representation, comparability, timeliness, understandability and relevance. The study concluded that there has been a significant improvement in these characteristics after implementing the IFRS compared to the period preceding the implementation of these standards. Karğın (2013) examined the effect of implementing IFRS on the relevance of the accounting information contained in the financial reports for listed companies in Turkey during the period 1998-2011. The study concluded that the relevance of accounting information after the implementation of IFRS has improved compared to the period preceding the implementation of these standards.

Agyei-Mensah (2013) studied the quality of financial reports, which were measured using four characteristics of accounting information: relevance, faithful representation, comparability and understandability before and after implementing IFRS for listed companies in the Ghana during the period 2006-2008. The study found a significant improvement in these characteristics in the 
period following the application of the IFRS compared to the period preceding the implementation of these standards. Kythreotis and Mare (2014) studied the effect of IFRS on the quality of financial reports for a sample of listed companies in 15 European countries over a period of 10 years from 2000-2009. The quality of financial reports was measured by two characteristics: faithful representation and relevance. The study concluded that there has been a significant improvement in relevance after implementing IFRS, while there was no significant effect on the faithful representation. Desokey and Mousa, (2014) studied the effect of IFRS on two characteristics of accounting information: relevance and predictive ability on a sample of listed companies in the Bahrain during the period 2005-2011. They concluded that the relevance has improved, while the predictive ability has decreased in the period after the implementation of IFRS.

Yurisandi and Puspitasari (2015) examined a sample of listed companies in Indonesia during the period 2009-2013 to explore whether there is an improvement in the quality of financial reports after the implementing IFRS. Their results indicated the there was an improvement in relevance, understandability, and comparability after the implementation of IFRS, while there was no significant improvement in the timeliness. They also found that the implementation of IFSR led to a significant decrease in faithful representation. Oraby (2017) studied the effect of IFRS on the relevance accounting information for a sample of listed banks in Saudi Arabia. The study concluded that the relevance of accounting information after the implementation of IFRS has improved significantly. Hassan (2019) analyzed the impact of the adoption of IFRS on the comparability of the financial reports of a sample of companies listed on the Saudi Stock Exchange that are expected to differ significantly from the generally accepted accounting standards in Saudi Arabia. To achieve this objective, he measured the quantitative impact of the application of IFRS on income figures and financial positions. The results of the study indicate that there are statistically significant differences between the variables resulting from the application of two sets of International Financial Reporting Standards adopted in Saudi Arabia and the Saudi (GAAPs). Desalegn (2020) studied the effect of IFRSs on the quality of financial reports for a sample of listed commercial banks in Ethiopia. The study concluded that there was as significant improvement in relevance, understandability, comparability, and faithful representation after the implementation of IFRS.

\section{Methodology and Procedures}

\section{Instrument Development}

This study is a cross-sectional survey that sought to collect field data on the opinions of financial statements preparers in Saudi commercial banks regarding the effect of implementing IFRS on the quality of financial statements. A questionnaire survey was prepared to explore the opinions of the participants regarding the effect of implementing IFRS on five of the qualitative characteristics of the accounting information, including two of fundamental characteristics: relevance, faithful representation and three of the enhancing characteristics: understandability, comparability, and timeliness. The questionnaire includes three sections. The first section is concerned with gathering some demographic information about the participants (e.g., gender, qualifications, years of experience), while the second and third sections include two sub- 
questionnaires. The first sub- questionnaire aims to explore the opinions of the participants on the five qualitative characteristics before implementing IFRS, while the second subquestionnaire aims to explore the opinions of the participants on the same five qualitative characteristics after implementation of IFRS. The participants were asked to express their opinions on the five qualitative characteristics in each of the two sub- questionnaires on a fivepoint Likert Scale anchored at 1 for very low and 5 for very high. To ensure content validity, the survey instrument was vetted by four academics with expertise in the disciplines of finance and accounting in three universities in Saudi Arabia. Based on their recommendations, some amendments were made on the questionnaire to improve its clarity. The questionnaires were administered and collected during July- August 2020 and they were developed in Arabic language.

\section{Sample}

The population of the study includes all the 12 commercial banks listed in the Saudi Stock Exchange. These banks have begun to implement IFRS with the year beginning on 1/1/2017 in accordance with the requirements issued by the Saudi Organization for Certified Public Accountants (SOCPA) as well as the Saudi Arabian Monetary Agency (SAMA), which is the authority supervising banks in Saudi Arabia. Thus, these banks have implemented local Saudi accounting standards before 2017 and have implemented IFRS since 2017 until now, which means that these banks have sufficient experience in implementing both types of accounting standards. 90 questionnaires were distributed to the members of the accounting departments concerned with preparing the financial statements in these banks. The participants were asked to complete these questionnaires and send them back to the researcher within three weeks of receiving them. The process of distributing and receiving the survey lists took place during the months of July and August 2020. After the end of the specified period, the number of lists sent to the researcher were 68 , out of the 90 questionnaires that were distributed, so that the response rate is approximately $75.5 \%$. Table (1) shows the demographic profiles of the research sample

Table 1: Demographic Profiles of the Respondents

\begin{tabular}{lll}
\hline Category & Scale & N= 68 (100\%) \\
\hline \multirow{2}{*}{ Gender } & Male & $53(78 \%)$ \\
& Female & $15(22 \%)$ \\
& Bachelor & $52(76.5 \%)$ \\
Qualification & Master & $14(20.5 \%)$ \\
& Doctorate & $2(3 \%)$ \\
& & \\
& Less than 10 year & $6(9 \%)$ \\
Working Experience & 10-15 year & $32(47 \%)$ \\
\hline
\end{tabular}




\begin{tabular}{ll}
\hline $15-20$ year & $19(28 \%)$ \\
More than 20 year & $11(16 \%)$
\end{tabular}

\section{Source: Author}

As shown in Table (1), the majority of the respondents are men. This is normal in the Saudi Arabia in light of the reluctance of women to work in commercial banks. Most of the respondents have a large number of years of experience, which means that they have sufficient experience in implementing local Saudi standards and IFRS for financial reporting, which increases the credibility of the opinions obtained from them. The educational background, qualifications and work experience indicate that the respondents would have a collective perspective on issues relating to the implementation of IFRS in Saudi Arabia. The purpose of the above analysis is to ensure that the questionnaire was completed by experienced and knowledgeable accountants who have concern and interest in accounting standards in Saudi commercial banks.

\section{Results and Discussion}

A descriptive statistic (particularly the mean) was used to establish the effect of the adoption of IFRS on financial reporting quality. Descriptive analysis was conducted to describe respondents' ratings for the effect of IFRS implementation in Saudi commercial banks on the five qualitative characteristics of accounting information. Table (2) shows the opinions of the respondents on the five qualitative characteristics before implementing IFRS, while Table (3) shows the opinions of the respondents on the same five qualitative characteristics after implementation of IFRS.

Table2: Descriptive Statistics for Post-IFRS Implementation

\begin{tabular}{cccccc}
\hline & N & Minimum & Maximum & Mean & $\begin{array}{c}\text { Std. } \\
\text { Deviation }\end{array}$ \\
\hline Relevance & 68 & 2 & 4 & 3.96 & 0.3032 \\
faithful representation & 68 & 3 & 5 & 4.23 & 0.2187 \\
understandability & 68 & 3 & 4 & 3.48 & 0.3421 \\
comparability & 68 & 2 & 5 & 4.67 & 0.2845 \\
timeliness & 68 & 3 & 5 & 4.52 & 0.2796 \\
\hline
\end{tabular}

Source: Author

Table 3: Descriptive Statistics for Pre-IFRS implementation

\begin{tabular}{cccccc}
\hline & N & Minimum & Maximum & Mean & $\begin{array}{c}\text { Std. } \\
\text { Deviation }\end{array}$ \\
\hline Relevance & 68 & 1 & 3 & 1.869 & 0.4785 \\
faithful representation & 68 & 1 & 3 & 1.756 & 0.4698 \\
\hline
\end{tabular}




\begin{tabular}{cccccc}
\hline understandability & 68 & 1 & 4 & 2.025 & 0.3968 \\
comparability & 68 & 1 & 3 & 1.356 & 0.4487 \\
timeliness & 68 & 1 & 3 & 1.419 & 0.4618 \\
\hline
\end{tabular}

\section{Source: Author}

A comparison between the data presented in Table 2 and Table 3 shows that there is an improvement in the mean evaluation of the respondents of the five qualitative characteristics of accounting information for commercial banks in Saudi Arabia after the implementation of IFRS. This indicates that the respondents believe that the implementation of IFRS leads to an improvement in the qualitative characteristics of accounting information, and then leads to an improvement in the quality of the financial statements for commercial banks in Saudi Arabia after the implementation of IFRS. To examine whether this improvement in the respondents 'perception on the qualitative characteristics of accounting information after implementing IFRS compared to their perception on these characteristics before implementing the standards was significant, a T-test for the difference between the mean of two non-independent samples was conducted. Table 4 presents the results of the T-test to test the difference between the means the five qualitative characteristics before and after implementing IFRS.

Table 4: Paired Sample Test

\begin{tabular}{ccccc}
\hline & $\begin{array}{c}\text { Mean } \\
\text { Post-IFRS }\end{array}$ & $\begin{array}{c}\text { Mean } \\
\text { Pre-IFRS }\end{array}$ & t- value & $\begin{array}{c}\text { Sig. } \\
\text { (2-tailed) }\end{array}$ \\
\hline Relevance & 3.96 & 1.869 & 1.350 & 0.001 \\
faithful representation & 4.23 & 1.756 & 1.062 & 0.000 \\
understandability & 3.48 & 2.025 & 1.029 & 0.000 \\
comparability & 4.67 & 1.356 & 0.365 & 0.000 \\
timeliness & 4.52 & 1.419 & 0.658 & 0.003 \\
\hline$P \leq 0.05$ & & & &
\end{tabular}

Source: Author

As shown in Table 4, the results of the T-test show that all of the differences between the evaluation means of all the qualitative characteristics of accounting information before and after implementing IFRS are statistically significant, which confirms that there is a significant improvement in the qualitative characteristics of accounting information in the financial statements of commercial banks after implementing IFSR compared to the period prior to the implementation of these standards. 


\section{Conclusion and Suggestion}

The globalization of financial markets has increased the need for a unified set of accounting standards for measurement and reporting financial transactions that are applicable on an international scale, as accounting information is one of the main sources for making decisions in these markets. As part of Saudi Arabia's vision towards diversifying sources of income instead of relying solely on oil as the only source of national income, creating job opportunities by encouraging investments, whether local or foreign, and encouraging Saudi companies to grow and expand regionally and internationally, the Saudi Organization for Certified Public Accountants (SOCPA) announced transition plan towards the application of IFRS. At the end of this plan in 2016, SOCPA adopted the full set of IFRS and obligated all companies registered in the Saudi Stock Exchange to apply this set of standards as of the fiscal year that begins on January 2017. The adoption of IFRS has received considerable research interest and there have been a growing number of studies conducted to explore the impact of IFRS adoption on financial statements quality.

This study is an extension of the prior studies by examining the impact of implementation of IFRS on the quality of the financial statements of commercial banks registered in Saudi Arabia, which were measured by five of the qualitative characteristics of accounting information: Relevance, faithful representation, understandability, comparability and timeliness. This study is a cross-sectional survey that sought to collect field data on the opinions of financial statements preparers in Saudi commercial banks regarding the effect of implementing IFRS on the quality of financial statements. A questionnaire survey has prepared to explore the opinions of the respondents regarding the effect of implementing IFRS on the five qualitative characteristics of the accounting information. The results of the study reveal that there is an improvement in the mean evaluation of the respondents of the five qualitative characteristics of accounting information for commercial banks in Saudi Arabia after the implementation of IFRS. This indicates that the respondents believe that the implementation of IFRS leads to an improvement in the qualitative characteristics of accounting information, and then leads to an improvement in the quality of the financial statements for commercial banks in Saudi Arabia after the implementation of IFRS.

\section{Conflict of Interest}

The author declares no conflict of interest

\section{Funding}

None

\section{References}

Agyei-Mensah, B. (2013). Adoption of International Financial Reporting Standards (IFRS) in Ghana and the Quality of Financial Statement Disclosures. International Journal of Accounting and Financial Reporting, 3(2), 269-286.

Barth, M., Landsman, W. \& Lang, M. (2008). International Accounting Standards and 
Accounting Quality. Journal of Accounting Research, 46(3), 67-498.

Botosan, C. (2004). Discussion of a framework for the analysis of risk communication. The International Journal of Accounting, 39(3), 289-295.

Chua, Y., Cheong, C. \& Gould, G. (2012). The Impact of Mandatory IFRS Adoption on Accounting Quality: Evidence from Australia. Journal of International Accounting Research, 11 (1), 119-146.

Cohen, J., Krishnamorthy, G. \& Wright, A. (2004). The corporate governance mosaic and financial reporting quality. Journal of Accounting Literature, 23(1), 87-152.

Desalegn, G. (2020). Does IFRS Adoption Improve Financial Reporting Quality? Evidence from Commercial Banks of Ethiopia. Research Journal of Finance and Accounting, 11(7), 18-24.

Desokey, A. \& Mousa, M. (2014). The Value Relevance and Predictability of IFRS Accounting Information: The Case of GCC Stock Markets. International Journal of Accounting and Financial Reporting, 4(2), 215-225.

Dimitropoulos. P., Asleriou, D., Kousenidis, D. \&Stergios, L. (2013). The impact of IFRS on accounting quality: Evidence from Greece. Advances in Accounting, 29(1), 108-123.

Hassan, M. (2019). Analysis of Effects of IFRS Adoption on the Comparability of Financial Reporting: Evidence from Saudi Listed Companies. Journal of Emerging Issues in Economics, Finance and Banking, 8(1), 2698-2714.

IASB. (2008, 2013). Exposure draft on an improved conceptual framework for financial reporting: The objective of financial reporting and qualitative characteristics of decisionuseful financial reporting information. London

Junior, J., Caldeira, J. \& Torrent, H. (2017). Effects of IFRS on Accounting Information Quality: Evidence for Brazil. International Journal of Economics and Finance, 9(5), 4457.

Karğın, S. (2013). The Impact of IFRS on the Value Relevance of Accounting Information: Evidence from Turkish Firms. International Journal of Economics and Finance, 5(4), 71-80.

Key, K. \& Kim, J. (2020). IFRS and accounting quality: Additional evidence from Korea. Journal of International Accounting, Auditing and Taxation, 39(1),100-116.

Kythreotis, A. \& Mare, S. (2014). Measurement Of Financial Reporting Quality Based On IFRS Conceptual Framework's Fundamental Qualitative Characteristics. European Journal of Accounting, Finance \& Business, 2(3), 4-29.

Liu, C., Yao, L. \& Hu, N. (2011). The Impact of IFRS on Accounting Quality in a Regulated Market: An Empirical Study of China. Journal of Accounting, Auditing and Finance, 26(4), 659-676.

Morais, A., Fialho, A. \& Dionísio, A. (2018). Is the accounting quality after the mandatory adoption of IFRS a random walk? Evidence from Europe. Journal of Applied Accounting Research, 19(3), 334-350.

Oraby, S. (2017). IFRS and Accounting Information Relevance: The Case of Saudi Arabia. Journal of Business \& Economic Policy, 4(1), 145-155.

Schipper, K. \& Vincent, L. (2003). Earnings Quality. Accounting Horizons, 17, 97-110 (Supplement).

Trimble, M. (2018). A reinvestigation into accounting quality following global IFRS 
adoption: Evidence via earnings distributions. Journal of International Accounting, Auditing and Taxation, 33(1), 18-39.

Yacoob, N. \& Ahmad, C. (2011). IFRS adoption and audit timeliness: evidence from Malaysia. the journal of American academy of business, 17(1), 1-7.

Wahyuni, E., Puspitasari, G. \&Puspitasari, E. (2020).Has IFRS improved Accounting Quality in Indonesia? A Systematic Literature Review of 2010-2016. Journal of Accounting and Investment, 21(1), 1-18.

Yurisandi, T. \&Puspitasari, E. (2015). Financial reporting quality before and after IFRS adoption using NiCE qualitative characteristics measurement. Procedia - Social and Behavioral Sciences, 11(2), $644-652$. 